\title{
The Relations among Environmental Performance, Environmental and Firm Performance
}

\author{
ALIA ARIESANTI* \\ Universitas Ahmad Dahlan
}

\begin{abstract}
Companies tend to disclose good news. If the company has good environmental performance, it will be disclosed in the financial statements. This disclosure of environmental information will enhance the reputation of the company; thus it will increase company performance. The research aims to reexamine the results of the previous study by analyzing the environmental disclosure as mediating the relationship between environmental performance and corporate performance. The archival research method is applied in this study. This study is investigate manufacturing companies listed in Indonesia Stock Exchange and listed in the PROPER program in 2011. The finding implies that the performance of the environmental effect on the company's performance through environmental disclosure.
\end{abstract}

Keyword: Environmental Performance, Disclosure, Financial Performance, PROPER.

Intisari: Perusahaan cenderung mengungkapkan berita baik. Jika perusahaan memiliki kinerja lingkungan yang baik, maka akan diungkapkan dalam laporan keuangan. Pengungkapan informasi lingkungan ini akan meningkatkan reputasi perusahaan; sehingga akan meningkatkan kinerja perusahaan. Penelitian ini bertujuan untuk menguji kembali hasil penelitian sebelumnya dengan menganalisis pengungkapan lingkungan sebagai mediasi hubungan antara kinerja lingkungan dan kinerja perusahaan. Metode penelitian arsip diterapkan dalam penelitian ini. Penelitian ini adalah menyelidiki perusahaan manufaktur yang terdaftar di Bursa Efek Indonesia dan terdaftar dalam program PROPER pada tahun 2011. Penemuan ini menyiratkan bahwa kinerja efek lingkungan pada kinerja perusahaan melalui pengungkapan lingkungan.

Kata kunci: Kinerja Lingkungan, Pengungkapan, Kinerja Keuangan, PROPER.

* Corresponding author: alia.ariesanti@act.uad.ac.id 


\section{Introduction}

Pollution, natural disasters, global warming, and other environmental damage have changed society's view that the environment must be maintained so that human life is not threatened. This change of view also affects the company, then the company's business activities do not damage the environment. The company reveals environment-oriented activity in their financial statements. Disclosure of information, especially for voluntary information in the financial statements will be done if the information is beneficial for the company (Berthelot et al., 2003). If the environmental information is good news, then the information will be disclosed in the financial statements (Al-Tuwaijri, et al., 2003; Arafat, Warokka, and Dewi, 2012; Lindrianasari, 2007). The company aims revealed environmental-based activities is to demonstrate to stakeholders that they have satisfied stakeholder expectations (Deegan, 2002).

Disclosure of environmental performance will have a positive impact on the company, which can improve the performance of the company. Companies that have complied with its environmental obligations, meaning the company has conducted good corporate governance. It means that the company is carried out efficiently and profitably (Arafat et al., 2012; Effiong et al., 2012). Lajili and Zeghal (2006) state that companies which disclose more social responsibility have better financial performance than companies that are less disclose. While Preston's research (1978) provides empirical evidence that the company has a higher return on equity (ROE) if the company disclose the environmental information than companies that do not (Murwaningsari, 2006).

Previous studies which studying the relationship between environmental performance, environmental disclosure, and corporate performance have been carried out. Still, on that point are no consistent results among these studies (Al-Tuwaijri et al., 2003; Arafat et al., 2012; Lindrianasari, 2007). This study aimed to review the effects of previous research by examining the environmental disclosure as mediating the relationship between environmental performance and corporate performance according to legitimacy theory. 


\subsection{Environmental Responsibility}

The business activities of the company cannot be separated from the various parties in the surrounding. The business activities of a company are not merely attempted to maximize profits for investors and creditors however it considers the interests of society and the environment. The concept of the entity theory adopted by the company, which is concerned with the investors and creditors in the company's business activities, then shifted to the stakeholder theory. Based on to stakeholder theory, welfare achieved by the company not merely to shareholders, but also to the interests of stakeholders. The term stakeholders refer to all parties affiliated with the company, that is suppliers, customers, employees, shareholders, management, and social. In addition to human welfare, the welfare of the company is also beneficial for the environment (Triyuwono, 2012). The company is considered as a mandate to spread mercy to all the worlds (human and other creatures).

According to legitimacy theory, companies found to be influenced by, and in turn influence upon, the society in which it operates (Deegan, 2002). The company will be able to sustain if the society believes that the existence of the company has benefits. The company will continue their business if the society believes that the values of the company in line with the values of society (Ikbal, 2012). Therefore, if companies want to operate continuously, the activity should consider the interests of society and even contribute to their lives.

Stakeholder and legitimacy theory explain management motivation to disclose environmental performance. Both theories look similar, looking at the integration between the company and its environment (van der Laan, 2009), but there are differences in its application. Stakeholder theory emphasizes the relationship between the organization and its stakeholders (Orij, 2010), while the legitimacy theory emphasizes the organization's efforts to maintain the "good image" of the society by maintaining ethics and norms. Legitimacy theory also focuses on stakeholders and recognizes the existence of heterogeneity and conflict among stakeholders (Moerman $\&$ van der Laan, 2005). 
Although some theories have been applied in explaining the motivation of management to provide environmental disclosure (political economy is used by Cooper \& Sherer (1984), and Setyorini \& Soedirman (2012); legitimacy theory used by Cho \& Patten, (2007) and Guthrie (2006); stakeholder theory used by Orij (2010), and Gray, Owen, and Maunders (1987) used an accountability approach), but the legitimacy theory is more appropriate to describe voluntary environmental exposure (Guthrie, 2006; Neu, 1998; van der Laan, 2009 ). The disclosure of voluntary information depends on the management policy on the amount and type of information, form of disclosure, and media of disclosure. Management applies this voluntary information as a way to convince stakeholders that the organization is managed following the desire of the community.

As the activities of the company have been in line and considered the interests of society and the environment, the company revealed these activities on the financial statements. The financial statements are the means applied by management to communicate the conditions of the company to the users of financial statements. The activity of the company referred to the environment are disclosed in social and environmental responsibility report.

\subsection{Disclosure of Environmental Information}

In Indonesia, until lately, social responsibility disclosure in the financial statements is voluntary. Statement of Financial Accounting Standards (SFAS) No. 1 paragraph 9 states that the company can submit additional statements such as environmental reports and assertions regarding the added value (the value added statement). This statement implies that the company does have to prepare a CSR report. Accounting standards in Indonesia do not yet require companies to disclose their social information, especially information about corporate responsibility to the environment.

Because it is voluntary, the disclosure of environmental information in financial statements cannot be maximal. If the information is considered to be an adverse impact, then the information is not disclosed (Berthelot et al., 2003). Companies tend 
to disclose information that is favorable to them because such information would give a good impression to the users of financial statements. Through the good information, management of the company delivers information that the company is in good condition, and they run the business activity in line with the societal expectation(Deegan and Rankin, 1997).

Disclosures by management tend not to fulfill the responsibility, but for strategic purposes. The company revealed various activities undertaken to demonstrate to stakeholders that they have been running the expectations of stakeholders (Deegan, 2002). Indeed, the disclosure in financial reporting not adequate because there is no conformity between the information disclosed and the actual performance (Lindrianasari, 2007).

Awareness of Indonesian company to report and disclose environmental accounting is weak. The obligation to report on the environmental impact, which is stipulated by the Ministry of Environmental Affairs is only disclosure of an unpublished (specific to the related government institutions) (Ja'far and Arifah, 2009). While Lindrianasari (2007) identified that the average company that cares about environmental conservation amounted to only 1.89 (from a score of 1 to 3). It implies that in Indonesia less than 50\% of companies listed on the Stock Exchange voluntarily allocate funds for environmental conservation. The reporting is also still limited to assign funds for environmental conservation, has not revealed how much the contribution funds for the environment. Only about 10 percent of which include the monetary amount for environmental conservation in addition to the financial statements or notes to the financial statements (in Nuswantara, 2008). Companies in Indonesia have a weak awareness of the importance of environmental disclosure

\subsection{Environmental Performance}

Corporate environmental performance is the performance of the company in creating a good environment (green business) (Suratno et al. (2006). Environmental performance of companies in the study was measured through a PROPER or Program Penilaian Peringkat Kinerja Perusahaan which is an instrument used by the Ministry of 
Environment to assess the level of compliance based on regulations. PROPER is announced to the public periodically, and then the public may determine the reputation of a company, depend on the degree of adherence.

Performance rating of the company in the management of the environment began to be developed Ministry of Environment, as one alternative to the environmental performance measurement instruments, since 1995. Application of this tool is made by disseminating the performance of each company to stakeholders on a national scale. The program is expected to encourage companies to improve environmental management performance. Thus the environmental impact of the company's activities can be minimized. The use of color on PROPER assessment is a form of communication to convey environmental performance to the public, ranging from the best in gold, green, blue, red, up to the worst, black. In simple terms, the public may know the level of corporate environmental performance by looking at the color of current ratings.

In 2005, the Ministry of Environment and Bank Indonesia signed a memorandum of understanding (MoU) as a follow-up of the Bank Indonesia Regulation Number $7 / 2 / \mathrm{PBI} / 2005$, regarding the determination of asset quality ratings for commercial banks. Based on this rule, companies that want to get a bank loan must show concern in environmental management.

\subsection{Company performance}

The primary objective of the company is to maximize shareholder wealth. In addition to the benefit of shareholders, the company's goal is also to ensure that scarce corporate resources can be allocated efficiently and provide economic benefits. Mirza and Imbuh (1999) state that the wealth or welfare of the owners (shareholders) will increase or maximum if the MVA also increase or maximum.

Besides EVA, measuring financial performance may also use the MVA. MVA measurements assess the impact of actions of managers of wealthy shareholders since the company was established, while the EVA was judging ineffectiveness of managers at the company (Brigham and Gapenski, 1999). Market Value Added is the total 
market value of all stocks and corporate debt, which means the number obtained by investors if all its investments in stocks and bonds sold in the financial market, reduced total invested capital (in the form of equity, retained earnings, debt, and debt capital markets through the bank). If MVA is positive means the manager succeeded in creating added value for the company otherwise, if the MVA is negative, then the manager failed to create added value for the company.

By the concept of MVA, the creation of value for shareholders is to maximize shareholder wealth, which is done by optimizing the difference between the market value of equity to the nominal amount invested by the investor in the company. This concept is a measure of financial performance externally, so instead of the market value of the company which is the product of the number of shares outstanding by the price of its market price. Since the company's market value has the disadvantage that for companies that have gone public, its market value will change when the new stock sale. Though an increase in market value in that way is not the real business of the company, so it can't be recognized as an achievement of the company's financial performance.

\section{Theoretical Framework and Hypothesis Development}

Legitimacy theory states that the company's disclosure is to shape the perception of the company's operations. The goal is to establish or maintain a public perception that the company's operations in line with community expectations. This goal will be achieved when of society uses the information disclosed in the financial statements (Deegan and Rankin, 1997). The good environmental performance will disclose in the annual report. This will attract the attention of the stakeholders because the stockholder will see the performance of the company, where they will invest. The higher the quality of the company in raising its environmental performance and the performance was later revealed in his annual report, it will be better the prestige of the company by stockholders and society.

Preston (1981) states that companies with good environmental performance and high disclosure, will position them as a company that has a useful activity, and quality 
of this disclosure will encourage the legitimacy of the of society. Also, research conducted by Al-Tuwaijri et al. (2004) provides empirical evidence that good environmental performance will encourage the disclosure of which is also good. Based on these explanations, the first hypothesis of this study is:

H1. There is the influence of environmental performance on environmental disclosures

Reporting environmental information does not provide economic benefits in the short term, but the impact directly or indirectly on the company's financial future. Now the business world is no longer just paying attention to the company's financial records alone (single bottom line) but has been covering aspects of the planet, people and profit. Thus, if a company gives an account of environmental conditions, the image of the company be increased or be good. Investors are more interested in the company that has a good image in the community because of the good image of the company, the higher the customer loyalty. Satyo (in Masnila, 2010) stated the presentation of the report relating to social and environmental activities provides many benefits for the company include improving the image of the company, preferred by consumers, and interested investors

Reporting on corporate environmental accounting is expected to increase the economic value added, compared with the companies that less concerned about environmental issues. Economic value added is one of the company's competitive advantages for the company. So environmental accounting encourages a competitive advantage for the company (Yuliusman, 2008). Deegan and Rankin (1997) stated that the respondent would act differently to investment decisions, depending on the availability of social information. Meanwhile, Diekers and Antal (1985) (in Lindrianasari, 2007) argued that social information for the benefit of stakeholders would affect the decisions they make.

Research conducted Lajili and Zeghal (2006) found empirical evidence that companies are disclosing more human capital (which is part of the CSR) has noted that financial performance better than the companies that disclose less information. 
While research conducted by Preston (1978) provide empirical evidence that the company has a higher return on equity (ROE) if they reveal their the sustainability activity (in Murwaningsari, 2009). Pava and Krausz (1996) (in Lindrianasari, 2007) explains that the company disclosed the information would not make the company lose stakeholders and companies that demonstrate social responsibility proved to have better performance compared to firms that do not show social responsibility. Based on these explanations, the second hypothesis of this study is:

\section{H2. There is the influence of environmental disclosures on corporate performance}

The concept of eco-efficiency states that there is a relationship between environmental performance and financial performance. It is because of the cost efficiency due to good environmental performance. Environmental performance can improve the effectiveness of the company or increase the competitive advantage for the efficient use of resources. The implication is that companies have good environmental performance will have higher profits than companies that are less good environmental performance (Derwall et al., 2005).

The impact of environmental performance on firm performance cannot be realized in the short term (Guenster et al., 2006). Several previous studies have provided empirical evidence that the environmental impact on portfolio performance (Derwall et al., 2005), operating performance and market value (Al-Tuwaijri et al., 2003; Arafat et al., 2012; Chan and Walter, 2013; Guenster et al., 2006).

H3. There is the influence of environmental performance on corporate performance.

Based on legitimacy theory, companies with good environmental performance will tend to disclose such information in the financial statements. The disclosures made by the company so that society can know their environmental activities of the company. Such information will shape public perception, which then responds by making economic decisions. Good understanding of society will lead the company to a great value. 
According to the previous studies, this study also considers the firm size as a control variable, because previous studies provide empirical evidence that the size of companies impacted on firm performance (Meng and Da, 2006; Rofelawaty, 2010; Zadeh, 2012). It is due to the difference between the risk borne by large companies to small companies. The political cost hypothesis states that large firms face greater political pressure when reporting excessive earnings. The higher the risk, the higher a company's profitability in exchange for the high risk.

H4. Environmental performance effect on firm performance through environmental disclosure

\section{Research Method}

A sample of this study is a manufacturing company listed on the Indonesia Stock Exchange in 2011. The sample of this research is the object of study that meets the following criteria:

a. Participate in PROPER (Program of Performance Rating in Environmental Management) in 2011;

b. The Company has a fiscal year end in December, for partial financial statements not included in this study

The number of samples in this study amounted to 32 companies.

\section{Measurement of Research Variables}

The variables in this study are the environmental performance, environmental disclosure, and corporate performance. Environmental performance is the performance of the company in creating a green environment (green). This variable was measured using PROPER. Currently, PROPER implementation was done by Decree of the Minister of Environment No 7 of 2008 on Corporate Performance Rating Program in Environmental Management. In general, performance rating PROPER divided into five colors, namely gold, green, blue, red and black. The company rated by using color and assessed respectively with the highest score of 5 for the gold, and the lowest is 1 for black. 
The environmental disclosure variable is measured using content analysis to determine the disclosure score of environmental responsibility. This score describes the area of the related disclosure presented by each company. This data is obtained from corporate disclosure through annual financial statements on disclosure of social and environmental responsibility by method score 1 for items disclosed and 0 if not disclosed. The environmental responsibility index in this study refers to the instrument developed by Sembiring (2005), i.e., for the environmental category of 13 items.

Performance variables are measured using market value added (MVA). The reason for using the MVA is because it shows the company's ability to provide value added (wealth) to investors from the company's activities. This variable is measured by the difference between the market value of the stock less the book value of shares. If MVA is positive, the company successfully delivers value added for the investors, otherwise if negative MVA means that the company failed to provide value added for investors.

\section{Result and Discussion}

Most of the sample firms have a blue performance, which amounted to 20 companies (59\%). It means that most companies only appropriate environmental management required by the rules and regulations. Awareness of companies in Indonesia, only to the extent to meet the minimum requirements set by the government. One company has a black performance, which means the company is willfully negligent pollution and environmental damage and violation of the laws or implement administrative sanctions. While there are four companies have a red performance $(12 \%)$, which means the company does not engage in environmental management as required.

One sample firm has a golden performance, which means that the company that has consistently demonstrated the superiority of the environment (environmental excellence) in the production process and services and implement ethical business and responsible to the community. Eight companies (24\%) had a green performance, which means it has to manage the environment more than required by the regulations 
(beyond compliance). They applied environmental management systems, efficient use of resources through the efforts of the 4Rs (Reduce, Reuse, Recycle and Recovery), and undertake social responsibility (CSR / Comdev) well.

Table 1

Frequency of Environmental Performance Criteria

\begin{tabular}{lcc}
\multicolumn{1}{c}{ Criteria } & Frequency & Percentage \\
\hline Black & 1 & $3 \%$ \\
Red & 4 & $13 \%$ \\
Blue & 18 & $56 \%$ \\
Green & 8 & $25 \%$ \\
Gold & 1 & $3 \%$ \\
& 32 & $100 \%$ \\
\hline
\end{tabular}

The average company only reveals four out of ten items the disclosure of environmental performance or only $40 \%$ of the items were disclosed. It shows that most companies still do not consider the importance of environmental disclosures in the financial statements. While to the average company performance as measured by market value added amounted to Rp10.207.360.750.000. MVA is positive which shows the average sample firm can provide value added to investors.

Tabel 2

Results ofhypothesis testing

\begin{tabular}{llcc}
\hline \multicolumn{1}{c}{ Exogenous variables } & Endogenous Variable & Coefficient & T value \\
\hline Environmental performance & Environmental disclosure & 0,580 & 11,284 \\
\hline Environmental disclosure & Firm performance & 0,180 & 3,001 \\
\hline Environmental performace & Firm performance & 0,299 & 2,033 \\
\hline Firm size & Environmental disclosure & 0,223 & 5,015 \\
\hline
\end{tabular}

Hypothesis 1 states that the disclosure of environmental performance affects the environment. The test results showed that the value of the path coefficient estimate of 0.580 with a positive value. It is suggested that the relationship between 
environmental performance with environmental disclosure is unidirectional. The tstatistic value of 11.284 which means above the critical value of 1.96. It implies that hypothesis 1 is supported. That is the effect on the environmental performance of environmental disclosure.

Hypothesis 2 states that environmental disclosures affect the firm's performance. The test results showed that the value of the path coefficient estimate of 0.180 with a positive direction. It suggests that the relationship between environmental disclosure and corporate performance is unidirectional. The t-statistic value of 3.001, which means above the critical value of 1.96. It implies that hypothesis 2 is supported. That is disclosure of environmental influence on environmental performance.

Hypothesis 3 states that the environmental performance affects the environmental performance. The test results showed that the value of the path coefficient estimate of 0.299 with a positive direction. It implies that the relationship between environmental performance and firm performance is unidirectional. The t-statistic value of 2.033, which means above the critical value of 1.96 . Thus hypothesis 3 is supported, the performance of the environmental influence on environmental performance.

Hypothesis 4 states that environmental performance affects firm performance through environmental disclosure. Hypothesis4 is tested by examining the direct effect of exogenous to endogenous variables and test the indirect effect. The indirect impact is calculated using the Sobel test. In statistics, the Sobel test is a method of testing the significance of a mediating effect. The test results showed that the value of the path coefficient estimate of 0.104 . The value of $t$ statistic of 2.13 with a probability of 0.044 . The probability value is below the significance value of 0.05 . It means that hypothesis 4 is supported. That is, the effect on the environmental performance affect firm performance through environmental disclosure.

Test results for the relationship between total assets on the disclosure of the environment item show that the value of the path coefficient estimate of 0.223 with a positive direction. The t-statistic value of 5.015, which means above the critical value of 1.96. That is, that the disclosure of firm size effect on the environment disclosure. These results indicate that the environmental performance influence on environmental 
disclosure. The results of this study are consistent with studies conducted by previous researchers (Al-Tuwaijri et al., 2003; Arafat et al., 2012; Ikbal, 2013; Lindrianasari, 2007; Rofelawaty, 2010). It means that companies with good environmental performance are likely to disclose in the financial statements.

When viewed from the average level of disclosure companies by $40 \%$, indicating that awareness of the company to reveal of environmental activities in Indonesia remains low. The low awareness of the company to disclose environmental accounting information due to the difficulty in disclosing information relating to the environment. It is not easy to express activities related to the environment in the financial statements, especially when presented in the form of monetary units. Users of financial statement prefer financial indicators, such as profitability, cash flow, dividend payments and net assets in decision-making (Deegan and Rankin, 1997). Therefore, the company prefers to disclose financial information than environmental activities. Also, environmental accounting practices are still debatable, such as regarding reporting purposes, the characteristics of the qualitative, the user of the reports, and the manner of presentation (Deegan, 2002).

This study provides empirical evidence on the effect of environmental performance on firm performance. The results of this study are consistent with results of previous studies (Arafat et al., 2012; Derwall et al., 2005; Guenster et al., 2006) and the concept of eco-efficiency. The company is trying to improve its environmental performance, i.e., minimizing pollution, waste processing, and reuse mean that the company has been doing cost efficiency. The implication that the profits or performance of the company will be increased.

Also, this study also supports the model of the relationship between environmental performance and corporate performance through environmental disclosure. This study supports the theory of legitimacy and stakeholder theory. Based on stakeholder theory, corporate obligations not only to shareholders but also to the stakeholders. It means that the company is responsible for the welfare of all parties involved in the company's operations. If the company's activities can be in harmony with the interests of the public, the company's business continuity will be maintained. 


\section{Graphic 1.}

Path coefficient diagram

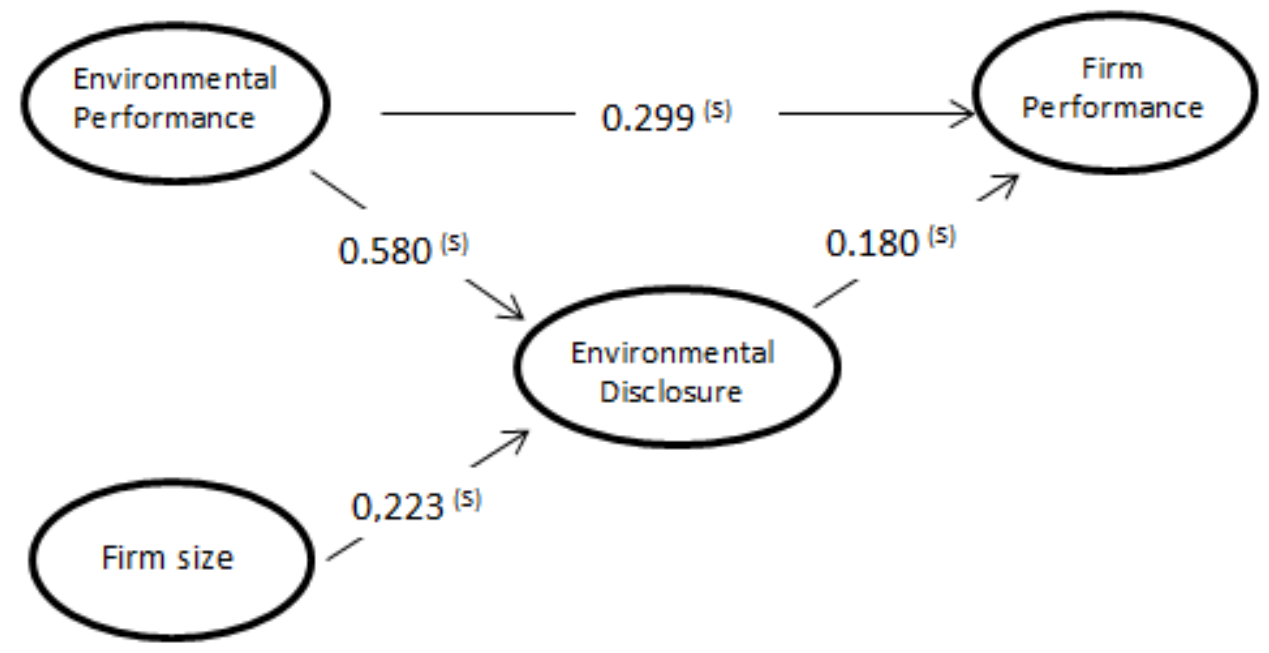

Legitimacy theory states that the purpose of the disclosure is to create a public perception of the company's operations, which is to establish or maintain a public perception that the company's operations in line with the expectations of society (Deegan and Rankin, 1997). Companies that care about the environment will improve its reputation. Good corporate reputation will be appreciated by investors or creditors to improve the performance of the company, which in the long run will impact the market value added.

\section{Conclusion, Limitation and Suggestion}

This study proposes a model of the relationship between environmental performance, environmental disclosure, and corporate performance. This model is supported statistically, but still weak statistical support. It is indicated by the probability level of 0.044 . Therefore, to support the model of the relationship between environmental performance, environmental disclosure, and corporate performance, the following study should reexamine this model. 
For subsequent studies, should also examine the relationship between environmental performance, economic performance, and environmental disclosure. It is because in this model the possibility of endogeneity problem (Al-Tuwaijri et al., 2003). Also, for each variable in this study can be developed with other measurements, so that the measurement can be more variable.

\section{Reference}

Al-Tuwaijri, S. A., Christensen, T. E., \& Hughes, K. E. (2004). The Relations Among Environmental Disclosure, Environmental Performance, and Economic Performance: A Simultaneous Equations Approach. Accounting, Organizations and Society, 29, 447-471.

Arafat, M. Y., Warokka, A., \& Dewi, S. R. (2012). Does Environmental Performance Really Matter? A Lesson from the Debate of Environmental Disclosure and Firm Performance. Journal of Organizational Management Studies, 2012(2).

Berthelot, S., Cormier, D., \& Magnan, M. (2003). Environmental Disclosure Research: Review And Synthesis. Journal of Accounting Literature, 22, 1-44.

Chan, P. T., \& Walter, T. (2013). Investment Performance of "Environmentally-Friendly" Firms and their Initial Public Offers and Seasoned Equity Offers.

Cho, C. H., \& Patten, D. M. (2007). The Role of Environmental Disclosures as Tools of Legitimacy: A Research Note. Accounting, Organizations and Society, 32, 639-647.

Deegan, C. (2002). Introduction: The legitimizing Effect of Social and Environmental Disclosures - a Theoretical Foundation. Accounting, Auditing \& Accountability Journal, 15(3), 282-311.

Deegan, C., \& Rankin, M. (1997). The Materiality of Environmental Information to Users of Annual Reports. Accounting, Auditing \& Accountability Journal, 10(4), 562. Retrieved from http://search.proquest.com/docview/211231070?accountid=46437

Derwall, J., Guenster, N., Bauer, R., \& Koedijk, K. (2005). The Eco-Efficiency Premium Puzzle. Financial Analysts, 61(2), 51-63.

Effiong, S. A., Akpan, E. I., \& Oti, P. A. (2012). Corporate Governance, Wealth Creation and Social Responsibility Accounting. Management Science and Engineering, 6(4), 110-114.

Guenster, N., Derwall, J., Bauer, R., \& Koedijk, K. (2006). The Economic Value of Corporate Eco-Efficiency The Economic Value of Corporate Eco-Efficiency.

Guthrie, J. (2006). Legitimacy Theory: A Story of Reporting Social and Environmental Matters Within the Australian Food and Beverage Industry. Sydney.

Ikbal, M. (2012). Hubungan Karakter Perusahaan dan Profitabilitas dengan Praktik Pengungkapan Sosial dan Lingkungan. Kinerja, 9(2), 25-36.

Ikbal, M. (2013). Pengaruh Implementasi Akuntansi Lingkungan dan Kinerja Lingkungan serta Pengungkapan Informasi Lingkungan sebagai Mediasi terhadap Nilai Perusahaan. Disertasi. Universitas Brawijaya. 
Lindrianasari. (2007). Hubungan antara Kinerja Lingkungan dan Kualitas Pengungkapan Lingkungan dengan Kinerja Ekonomi Perusahaan di Indonesia. Jurnal Akuntansi \& Auditing Indonesia, 11(2), 159-172.

Meng, L. W., \& Da, Y. (2006). Corporate Social Performance, Corporate Financial Performance, and Firm Size: A Meta-Analysis. American Academy of Business, 8(1), 163.

Moerman, L., \& van der Laan, S. (2005). Social reporting in the tobacco industry: all smoke and mirrors? Accounting, Auditing \& Accountability Journal, 18(3), 374-389. https://doi.org/10.1108/09513570510600747

Murwaningsari, E. (2006). Responsibilities dan Corporate Financial Performance Dalam Satu Continuum. Jurnal Akuntansi Dan Keuangan, 11(1), 30-41.

Neu, D. (1998). Managing Public Impressions: Environmental Disclosures In Annual Reports. Accounting, Organizations and Society, 23(3), 265-282.

Orij, R. (2010). Corporate Social Disclosures in the Context of National Cultures and Stakeholder Theory. Accounting, Auditing \& Accountability Journal, 23(7), 868-889. https://doi.org/10.1108/09513571011080162

Rofelawaty, B. (2010). Analisis Determinan Tingkat Pengungkapan Lingkungan Dan Dampaknya Terhadap Reputasi Dan Nilai Perusahaan. Disertasi. Brawijaya University.

Sembiring, E. R. (2005). Karakteristik Perusahaan dan Pengungkapan Tanggung Jawab Sosial: Studi Empiris pada Perusahaan yang Tercatat di Bursa Efek Jakarta. Simposium Nasional Akuntansi XVI, (September), 379-395.

Setyorini, C. T., \& Soedirman, U. J. (2012). Corporate Social and Environmental Disclosure: A Positive Accounting Theory View Point. International Journal of Business and Social Science, 3(9), 152-164.

Van der Laan, S. (2009). The Role of Theory in Explaining Motivation for Corporate Social Disclosures: Voluntary Disclosures vs. ' Solicited ' Disclosures. Australasian Accounting, Business and Finance Journal, 3(4).

Zadeh, F. O. (2012). Firm Size As Company 's Characteristic and Level of Risk Disclosure : Review of Theories and Literatures, 3(17), 9-18. 
The Indonesian Journal of Accounting Research - Jan, Vol. 20, No.1 , 2017

intentionally blank 